\title{
Development of a Telecommunication Company's Accounts Receivable Management System
}

\author{
Yulia V. Lazich ${ }^{1 *[O R C I D ~ 0000-0003-1425-8398], ~}$ \\ Irina N. Popova 2[ORCID 0000-0003-1477-9329]
}

\author{
${ }^{1}$ Yaroslav-the-Wise Novgorod State University, Veliky Novgorod, Russia \\ ${ }^{2}$ Ural State University of Economics, Ekaterinburg, Russia \\ Yuliya.Kolmagorova@novsu.ru
}

\begin{abstract}
The purpose of the study is to develop practical proposals for optimizing the management system of accounts receivable of telecommunications company customers, considering industry specifics. In the scientific literature, the issues of managing accounts receivable, improving its quality, and improving collection methods are covered quite widely, but there are not enough publications reflecting the current features of managing customer debt in telecommunications companies. The study was conducted based on a large telecommunications company operating in the market of Moscow and the Moscow region (Russia). During the study, standard methods of financial analysis were used, the main source of information was management accounting data, as well as internal regulations. During the analysis, it was found that, due to industry specifics, almost all accounts receivable from buyers and customers are overdue, and the least disciplined are the customers of the B2O segment. The main opportunities to improve the quality of debt and accelerate its turnover are associated with the segment of legal entities. Based on the analysis of the practice of managing customer accounts receivable, proposals were developed aimed at accelerating its turnover and reducing the likelihood of bad debts. Based on the results of the study, changes were made to the existing regulations for managing accounts receivable in the company under study. The proposed directions of optimization of the customer accounts receivable management system, developed for a specific company, may be relevant for other enterprises providing communication services, since they reflect the industry features of this process. The effectiveness of the implementation of the proposed measures is associated with the release of funds invested in accounts receivable, which can be used to finance the company's development projects.
\end{abstract}

Keywords: accounts receivable, turnover acceleration, telecommunications company, collection methods, financial management

\section{INTRODUCTION}

The market situation in many industries requires businesses to take the most flexible approaches to the issue of paying for products by customers, this is one of the available ways to expand the sales market. Accounts receivable are a constant companion of commercial activity. However, if the process of managing it is built inefficiently, the organization will face difficulties with liquidity, and subsequently with the return of the debt that arose because of such a process.

The problem of formation and accumulation of accounts receivable at enterprises is one of the root causes of cash gaps, delays in payments on their obligations, as well as sequestration of operating and investment activities of companies, which significantly limits the possibility of development and ensuring competitiveness in the long term $[1,2]$.

There are no significant contradictions in the interpretation of the essence of receivables as an economic category in the scientific literature. Most scientists consider it as a working capital management tool [3-5]. Most often, the concept of accounts receivable is interpreted as the number of debts owed by third parties (legal entities and individuals) to an organization arising because of financial and economic transactions. It is obvious 
that the provision of deferred payment for goods or services causes a diversion of funds from turnover and associated losses. Thus, accounts receivable, on the one hand, contributes to revenue growth, and on the other hand, causes losses associated with the need to refinance it.

In the studies of domestic and foreign scientists, a wide variety of causes and factors affecting the quality and amount of accounts receivable are highlighted $[3,5]$.

From the whole set of reasons, two main ones can be distinguished: the first one determines cases when the client intentionally and consciously creates and increases debt without taking any action to repay it, and the company does not have a mechanism for assessing the solvency and reliability of the client; the second reason is the low efficiency of the debt management process within the company, as a result of which there are problems with liquidity, as well as with the return of receivables.

In the telecommunications sector, the management of accounts receivable is significantly influenced by the specifics of the industry. The subscriber bases of companies' number in the hundreds of thousands and even millions of numbers, and the services provided, and tariff plans are very diverse, which significantly complicates the processes of debt collection [6].

The organization of settlements with clients is carried out by a billing system, which is, in fact, a network software and hardware complex [7].

For a telecom operator providing services with their post-payment within a specified period, the greatest interest is to prevent the occurrence (or reduction) of overdue and uncollectible receivables, since this entails direct financial losses.

Existing statistics show that even a small delay reduces the probability of debt collection, with a delay in payment of a year or more, the probability of its repayment drops by more than $50 \%$, and after two years it is close to zero [4].

The telecommunications industry, compared with a few other industries, suffered less due to the consequences of restrictions imposed in connection with the COVID-19 pandemic, but they largely affected the solvency of several customers of telecommunications companies, which eventually led financial managers to re-analyze the entire chain of business processes and identify weaknesses in long-established algorithms and research procedures.
The problems of optimizing the customer accounts receivable of a telecommunications company are the subject of this study.

\section{MATERIALS AND METHODS}

The purpose of the study is to develop practical recommendations for improving the efficiency of managing accounts receivable of buyers and customers in a telecommunications company. The object of the study was a large telecommunications company LLC "XXX", which provides communication services on the territory of Moscow and the Moscow region (Russia). To maintain the confidentiality of the information provided, the company name is not disclosed.

During the study, the following tasks were solved:

- analyzed the state, structure and dynamics of accounts receivable of the telecommunications industry company, taking into account its specifics for 20182020; special attention was paid to the study of overdue debt;

- studied the practice of managing accounts receivable in the telecommunications industry;

- identified points of efficiency growth in existing business processes and developed practical recommendations for improving the management of customer accounts receivable.

The information basis of the study was the company's financial statements, management accounting data, relevant internal documentation.

The methodological basis of the work was the scientific works of Russian and foreign scientists in the field of financial management and corporate governance $[2-5,8]$, methodological approaches to the analysis and management of accounts receivable [9], including publications revealing the problems and specifics of accounts receivable management at enterprises of the telecommunications industry [10].

When performing scientific research, general methods (observation, comparison, analysis, and synthesis), as well as methods of financial analysis (vertical, horizontal, coefficient) were used.

\section{RESULTS}

Accounts receivable represent the most significant part of the working capital of any 
organization in the telecommunications sector, therefore, competent management of it is the most important task of financial services. The development of management decisions, as a rule, is based on the results of the analysis, in connection with which the state and trends in the accounts receivable of the company under study were analyzed. Of particular interest in solving the tasks is the accounts receivable of buyers and customers. The share of customer debt in the structure of the total debt of the studied telecommunications company LLC "XXX" in 2020 increased and amounted to $34 \%$ at the end of the year.

LLC "XXX" provides a deferred payment for 25 days, and the average repayment period in 2020 was 51 days. At the same time, the bill for services is mainly issued on the first day of each month. Thus, almost all accounts receivable of buyers and customers, reflected at the end of the period, is overdue, because due to the specifics of the company, it must be repaid before the $25^{\text {th }}$ of the month.

The company under study has a large share of bad debts that arose more than a year ago (at the end of 2020 it amounted to $88 \%$ ), but the main reason for this situation is the fact that it is not written off in a timely manner. Considering the industry specifics, as well as based on the practice of financial managers of LLC "XXX", debt with a maturity of more than a year is considered as hopeless, and work on it is practically not carried out.

Thus, it is advisable to accept debt for a period of up to a year as the main object of accounts receivable management in telecommunications companies.

The specifics of the activities of a large telecommunications company involves the organization of a few business processes, considering the serviced segment, among which the following are distinguished:

- $\mathrm{B} 2 \mathrm{C}$ - individuals;

- B2B - legal entities;

- $\mathrm{B} 2 \mathrm{G}-$ public authorities and structures with state participation of more than $50 \%$;

- $\mathrm{B} 2 \mathrm{O}$ - telecom carrier.

In the structure of accounts receivable of the company "XXX", the largest share is the debt of customers of the $\mathrm{B} 2 \mathrm{~B}+\mathrm{B} 2 \mathrm{G}$ segments $(57.5 \%$ at the end of 2020), and the smallest is the B2O segment $(11.6 \%)$. The results of the analysis of the company's customer debt for up to a year in the context of segments are clearly presented in Figure 1.

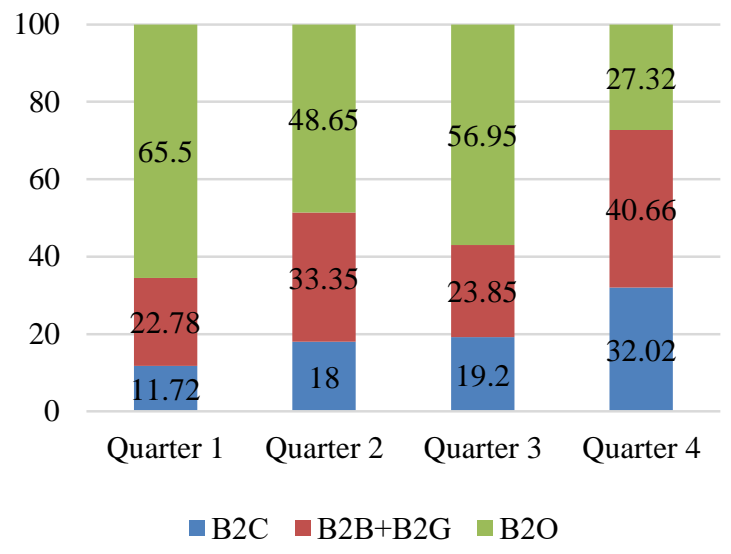

Figure 1. Structure of accounts receivable by time of occurrence in the context of customer segments, at the end of the quarter 2020,\%

Source: Compiled by the authors

It should be noted that at the end of the fourth quarter, $32.03 \%$ of the debt is due to services provided to individuals. This is due to the fact that debt collection from individuals is fraught with a number of difficulties, and the possibilities of accelerating repayment are quite limited. There is also an obvious increase in the share of debt owed by legal entities and public authorities - a little less than 2 times compared to the first quarter. The structure of debt with a maturity of up to a year has changed markedly throughout the year. If at the end of the first quarter it was dominated by the debt of customers of the $\mathrm{B} 2 \mathrm{O}$ segment $(65.5 \%)$, then at the end of the fourth quarter its share decreased to $27.32 \%$. The share of debt owed by individuals increased by $20.3 \%$, and customers of the B2B+B2G sector - by $17.88 \%$.

When managing accounts receivable of customers of the $\mathrm{B} 2 \mathrm{O}$ segment, the company actively uses a netting scheme, since many customers are simultaneously suppliers of LLC "XXX". At the same time, there is a simultaneous repayment of accounts payable and receivables. The active development of the inter-operator interaction market is specific to the telecommunications industry.

Based on the processing of information for 20192020, average figures (collection coefficients) were obtained that characterize the repayment of accounts receivable of XXX LLC (Table 1).

Based on the calculated collection coefficients, it can be concluded that the least disciplined in terms 
of debt repayment are customers-telecom operators (B2O). And it is in this segment that the largest percentage of bad debts is formed $-1.13 \%$ of services rendered are not paid.

Table 1. Coefficients of collection of accounts receivable by segment, \%

\begin{tabular}{|c|c|c|c|c|}
\hline \multirow{2}{*}{ Repayment Period } & \multirow{2}{*}{ Total } & \multicolumn{3}{|c|}{ Including by Segments } \\
\hline & & B2C & $\mathrm{B2B}+\mathrm{B2} \mathrm{G}$ & $\mathrm{B20}$ \\
\hline Within a month after invoicing for services & 88.12 & 94.89 & 92.64 & 56.36 \\
\hline During the first month following the baseline & 8.36 & 3.42 & 5.72 & 30.44 \\
\hline During the second month following the baseline & 1.40 & 0.81 & 0.58 & 6.17 \\
\hline During the third month following the baseline & 0.78 & 0.37 & 0.31 & 3.42 \\
\hline The balance of outstanding debt one year after its incurrence & 0.75 & 0.84 & 0.59 & 1.13 \\
\hline
\end{tabular}

Soyrce: Compiled by the authors

In general, more than $88 \%$ of the company's debt is paid on time - within a month after invoicing, another $8.36 \%$ delay payment by an average of a month, and $0.75 \%$ of revenue remains unpaid a year after the provision of services.

The main functions for managing accounts receivable in LLC "XXX" are implemented by employees of the Settlement Department based on the Regulation on Client Accounts Receivable Management. The evaluation of the effectiveness of the work is carried out using an established system of criteria. Their dynamics for 2018-2020 is positive, but the target value has been achieved only in terms of turnover indicators. Indicators reflecting the quality of debt have not reached the target level.

The existing practice of managing accounts receivable in the company under study can be recognized as effective. Preventive measures are taken before the identification of doubtful accounts receivable and include a preliminary check of counterparties; work with regular customers; receiving an advance. When identifying doubtful debts, measures are taken for its pre-trial recovery by sending letters, telephone conversations, personal communication with debtors, statements of claim are sent to judicial authorities, interaction is carried out with collection agencies engaged in collecting receivables.

The efficiency of debt repayment due to the involvement of collectors, defined as the ratio of revenue minus remuneration to collectors to the amount of debt transferred for collection, grew annually and in 2020 amounted to $38.6 \%$. The company is actively working on the transition with its customers to an electronic document management system (EDMS), which allows, with full reliability of document delivery, to significantly save time and financial resources.

At the same time, during the research, optimization opportunities were identified, the main purpose of which is to accelerate turnover and reduce losses from non-repayment of debts.

One of the main problems identified during the analysis of the company's accounts receivable is a significant amount of uncollectible debt, which is practically unrealistic to recover. It is necessary to write off such debts in a timely manner, but it is advisable to strengthen work to reduce the likelihood of such a low-quality debt. This can be achieved by supplementing the ABC analysis table of debtorslegal entities with a register of aging of their accounts, which will allow identifying a pool of systemic debtors with whom it is advisable to renegotiate contracts for an advance settlement system. In addition, it is advisable to check the reliability of the most significant customers based on a specialized service using a wide system of indicators.

According to the existing regulations for managing customer accounts receivable, unpaid debts are transferred to collectors for demand after 60 days after invoicing for services rendered, while the payment period expires after 25 days. A month after the invoice is issued, the provision of services to the client is blocked. At the same time, even if there are doubts that the debtor does not plan to pay the debt at all, it is impossible to transfer the debt to collectors for demand earlier, since the billing system generates invoices once a month, after processing all traffic. And without the final data, the company cannot transfer debts to collectors, and it turns out that if the client was conditionally blocked at the beginning of the month, then you must lose another month before transferring to collectors. To reduce the loss of time between blocking the client and transferring it to collectors, it is proposed to transfer part of the overdue debt for collection to the employees of the Settlement Department before transferring it to collectors and create additional motivation for them to recover in the amount of a fixed percentage of the recovered amount. 
The study of the customer accounts receivable management regulations has shown that the company has a time-stretched business process associated with the closing of the billing period, the issuance of primary documents and the collection of accounts receivable. To reduce the closing time of the billing period, it is proposed to create a month closing card with an indication of all necessary procedures, fix strict deadlines for the start time and duration of each procedure. It is possible to partially reduce the loss of time by automating the procedures for approving the transfer of clients (sole proprietors and legal entities) with an income of up to 20 thousand rubles. for blocking. For other clients who will also undergo the approval procedure, it is necessary to form a dialog box in CRM, through which the approval will take place online with data fixation in the CIS (corporate information system). To reduce the time required for printing and sending documents, it is also advisable to automate the formation of reconciliation reports and to ensure the possibility of automatically launching such mailing to debtors. Currently, invoices are sent to customers on the 3rd-4th of the month, an electronic set is sent out on the 6th-7th, and another 3-4 days are spent on printing and sending paper copies.

A significant factor in working with accounts receivable are the ways of delivering primary documents to customers. Practically in all contracts concluded now there is a phrase that payment is made in the presence of primary documents, therefore, on the part of the creditor, the absence of documents can cause the formation of debt, and on the part of the debtor - a formal basis for nonpayment of debt. Therefore, it is necessary to optimize the methods of document delivery.

When working with legal entities, the situation with the delivery of primary documents can be significantly simplified if an EDM agreement is signed [10]. As practice shows, this method of document delivery reduces the delivery time by 10 30 calendar days, depending on the distance of the counterparty. By maximizing the use of EDM with your customers, you can significantly speed up the turnover of accounts receivable, as well as reduce the cost of sending documents on paper and eliminate the risk of loss or damage to accounts. However, currently only $53.4 \%$ of the clients of the company under study use EDM. In this regard, it is necessary to intensify work on the transition of clients to EDM, for which it is proposed to introduce additional motivation for employees of the Settlement Department in a fixed amount for the transfer of each "paper" client to EDMS. It is also advisable to strengthen information work with customers about the benefits of using EDM, as well as to offer a partner discount from the EDM system to the company's customers for a unit of delivery.

\section{DISCUSSION}

The offered directions of accelerating the turnover of customer accounts receivable take into account the specifics of the telecommunications industry companies, their use in a complex will increase the efficiency of debt management.

The methodological approaches presented in scientific publications to assess the effectiveness of the accounts receivable management system do not have significant differences and are based on the calculation of various criteria reflecting the quality of accounts receivable, its turnover and the payment behavior of customers.

The effectiveness of the developed proposals will be expressed in accelerating the turnover of accounts receivable, reducing the amounts of bad debts. In scientific works, various sets of indicators for evaluating the effectiveness of the customer accounts receivable management system are proposed, one way or another reflecting turnover, quality, and the number of bad debts. The system for evaluating the effectiveness of the management of accounts receivable of buyers and customers at LLC "XXX" includes three main indicators:

- the ratio of overdue accounts receivable to the revenue of the corresponding period, \%;

- turnover period of customer accounts receivable, days;

- the balance of outstanding debt one year after its occurrence, $\%$.

The acceleration of turnover will be achieved by reducing the closing time of the billing period; reducing the time for printing and sending documents; automating the procedure for approving customers for blocking; increasing the proportion of customers who switched to EDM.

Reduction of debt that is uncollectible is possible by compiling a register of aging accounts of debtors (monthly); using a counterparty verification service that provides extensive information about the reliability of customers; transferring overdue debt to employees before transferring it to collectors for additional motivation, since the smaller the delay, the easier it is to recover the debt.

As a result of the acceleration of the turnover of 
accounts receivable, the number of investments in accounts receivable will decrease. The released funds can be directed to the development of the company, to reduce the debt burden, or to invest in nominal directions for the company.

\section{CONCLUSION}

The analysis of the management of accounts receivable of a telecommunications company revealed a few features of this process due to industry specifics.

Despite the sufficient efficiency of the accounts receivable management system of buyers and customers at the enterprise under study, the possibilities of its further optimization were identified, mainly aimed at improving the quality of debt and accelerating its turnover. The main opportunities for debt optimization are related to the segment of legal entities.

Proposals developed for a specific company aimed at accelerating the turnover of customer accounts receivable and reducing the likelihood of bad debts may be relevant for other companies in the telecommunications industry.

\section{AUTHORS' CONTRIBUTIONS}

The authors made an equal contribution to the study: collection and analysis of material; definition of goals and objectives, research methods; formulation and scientific substantiation of conclusions, registration of key research results in the form of an article.

\section{REFERENCES}

[1] M.Sh. Oganyan, "Improving the principles of financial planning at the enterprise", The Manager, 2012, vol. 11-12(39-40), pp. 42-45. (In Russ.).

[2] L. Zaporozhtseva, V. Malitskaya, M. Chirkova, Yu. Tkacheva, I. Kuznetsova, "Financial Mechanism for Commercial Organization
Developnent: Vector Approach", International Transaction Journal of Engineering, Management and Applied Sciences and Technologies, 2020, vol. 11(7). DOI: 10.14456/itjemast.2020.122

[3] E.F. Brigham, J. Houston, "Financial management: crash course" [Finansoviy menedjment: ekspress kurs], SPb.: Piter, 2016, 590 p. (In Russ.).

[4] V.V. Kovalev, V.V. Kovalev, [“Corporate finance" [Korporativniye finansy], Moscow: Prospekt, 2018, 639 p. (In Russ.).

[5] L.G. Danilova, "Features of management accounting accounts receivable and accounts payable”, Entrepreneur's Guide, 2017, vol. (36), pp. 102-110. (In Russ.).

[6] A.A. Kobylko, "Telecommunication Ecosystems: Special Features of Management and Interaction", The Manager, 2020, vol. 11(1), pp. 15-23. DOI: 10.29141/22185003-2020-11-1-2

[7] E.V. Tretyakova, "Payment management for telecommunication services in the post-crisis period" [Organizaciya raschetov za telekommunikacionnye uslugi $\mathrm{v}$ postkrizisnyj period], Finance and Credit, 2013, vol. 20(548), pp. 65-72. (In Russ.).

[8] V. Kleiner, "Corporate Governance and the Efficiency of Company's Operation”, Voprosy Ekonomiki, 2008, vol. 10, pp. 32-48. (In Russ.). DOI: 10.32609/0042-8736-2006-3-86-103

[9] A.D. Sheremet, "Analysis and diagnostics of financial and economic activity for the enterprise" [Analiz i diagnostika finansovokhozyaystvennoy deyatel'nosti predpriyatiya], Moscow: INFRA-M, 2019. (In Russ.).

[10] N.M. Rozanova, A.V. Yushin, "Transformation mechanism of network markets in digital era", Terra Economicus, 2015, vol. 13(1), pp. 73-88. (In Russ.). 